XVIII. INQUA Congress

20-27 July 2011 in Bern, Switzerland

PALCOMM \# 14: Lacustrine deep drilling records of Pleistocene climates: How far have we come?

\title{
Sedimentological and stratigraphic framework of the several hundred thousand years old lacustrine record from Lake Van, Turkey
}

Mona Stockhecke*, a, Flavio S. Anselmetti*, Ola Kwiecien*, Mike Sturm, and PALEOVAN scientific team

*Eawag, Swiss Federal Institute of Aquatic Science and Technology, Überlandstrasse 133, 8600 Dübendorf, Switzerland

${ }^{\mathrm{a} C}$ Corresponding author Mona.Stockhecke@eawag.ch

Within the frame of the International Continental Scientific Drilling Program (ICDP) project PALEOVAN, a long and continuous sediment record from Lake Van, a closed lake situated in a climatically sensitive semiarid and tectonically active region in Eastern Anatolia, has been drilled in summer 2010. At two sites, Ahlat Ridge and Northern Basin, sedimentary records of 220 and $140 \mathrm{~m}$ were recovered, respectively. With basal ages possibly around 500'000 years, these records span several glacial-interglacial cycles and reach back until the lake's initial transgression in the Middle Pleistocene.

First results from ongoing analysis of core-catcher samples and newly opened cores document the sedimentological and geochemical succession. Two composite profiles of the drill sites were defined. Core catcher-based geochemical data such as proxies of lake's productivity and catchment alterations show large variations and reflect a rich paleoenvironmental history. Most of the $220 \mathrm{~m}$ thick succession consists of carbonate mud, mostly sub-mm-thick laminated and interbedded by either homogenous mud or pyroclastic cm-thick layers. The lowermost sediments from the Ahlat Ridge site represent the initial lake transition as the drilling could not penetrate further and the seismic data indicates coincidence with the 'acoustic' basement. Such an early transgressive state of the lake's history is also supported by the lithology consisting of a gravel unit as an indicator of a beach-like environment, which is overlain by sand deposits containing fresh-water gastropods (Bithynia). Above 200 mblf, the laminated mud clearly indicates that the lake was already deep enough to form anoxic bottom water as the laminations were preserved. This unique paleoclimate archive indicates that great changes of the depositional conditions occurred that hint to a fascinating evolution of the environment and has ideal prerequisites for the investigation of the Quaternary climate evolution in the Near East. 